\title{
Penggunaan Media Kahoot Pada Pembelajaran Tematik Terhadap Hasil Belajar Siswa Kelas V SDI Nurul Iman
}

\section{Zuni Eka Tiyas Rifayanti, Husnul Mu'asyaroh}

\author{
STKIP Bina Insan Mandiri \\ zunieka@stkipbim.stkipbim.ac.id
}

\section{Article History}

received 22/5/2021

revised $5 / 11 / 2021$

accepted 24/12/2021

\begin{abstract}
As teachers, in this era we must understand that the era of education with the use of digital technology is a hallmark of education in the 4.0 revolution era where teachers in the digital era are required to be able to make changes in the delivery of material to students to make it easier to accept. The purpose of this study is to (1) describe the use of kahoot media (2) describe student learning outcomes with the use of kahoot media (3) describe student responses (4) describe barriers to the use of kahoot media. The research method used in this study is a research method with a qualitative approach. Which aims to describe the effect of using kahoot media in thematic learning that focuses on the material of the proclamation event. Data collection instruments used interview instruments, learning outcomes instruments and student response questionnaires. The subjects studied were fifth grade students of the Islamic Elementary School Nurul Iman. The results of this study indicate that using kahoot media can help teachers in conditioning students, besides that this media can also make students understand the material given better. However, in its use there are obstacles to the internet network connection and the lack of the number of devices owned by students.
\end{abstract}

Keywords: kahoot media, learning outcomes, thematic learning

\begin{abstract}
Abstrak
Sebagai guru, di era kali ini kita harus paham bahwa era Pendidikan dengan pemanfaatan teknologi digital merupakan ciri dari Pendidikan di era revolusi 4.0 yang dimana guru di era digital diharuskan mampu membuat perubahan dalam penyampaian materi kepada siswa agar lebih mudah diterima. Tujuan dari penelitian ini adalah untuk (1) mendeskripsikan penggunaan media kahoot (2) mendeskripsikan hasil belajar siswa dengan penggunaan media kahoot (3) mendeskripsikan respon siswa (4) mendeskripsikan hambatan pada penggunaan media kahoot. Metode penelitian yang digunakan dalam penelitian ini adalah metode penelitian dengan pendekatan kualitatif. Yang bertujuan untuk mendeskripsikan pengaruh penggunaan media kahoot dalam pembelajaran Tematik yang berfokus pada materi peristiwa proklamasi. Instrument pengumpulan data menggunakkan instrument wawancara, instrument hasil belajar dan instrument angket respon siswa sedangkan data di analisis dengan pengumpulan data,reduksi data, penyajian data, dan ferivikasi data. Subjek yang diteliti adalah siswa kelas V Sekolah Dasar Islam Nurul Iman. Hasil dari penelitian ini menunjukkan bahwa dengan menggunnakan media kahoot ini dapat membantu guru dalam mengkondisikan siswa, selain itu media ini juga dapat membuat siswa lebih memahami materi yang diberikan. Namun dalam penggunaannya terdapat hambatan pada koneksi jaringan internet dan kurangnya jumlah perangkat yang dimiliki oleh siswa.
\end{abstract}

Kata kunci: media kahoot, hasil belajar, pembelajaran tematik 


\section{PENDAHULUAN}

Teknologi menjadi alat yang digunakan dalam menyediakan keperluan seperti barang untuk kelangsungan dan kenyamanan hidup manusia. Teknologi menjadi hal yang tidak dapat terlepas dari masyarakat disekitar kita, teknologi komunikasi seperti gawai menjadi salah satu contohnya. Di masa revolusi 4.0 atau yang disebut dengan era digital dan berkembang begitu pesat membawa dampak luar biasa pada semua aspek tanpa terkecuali pada dunia pendidikan. Perkembangan teknologi yang semakin pesat membuat dunia pendidikan dituntut untuk melakukan perubahan. Karena kita tidak hanya menghadapi mesin digital melainkan juga karakteristik siswa dalam memotivasi belajarnya.

Di era digital ini, banyak siswa telah memiliki media gawai yang dimiliki secara pribadi. Hal ini menimbulkan dampak baik dan buruk bagi perkembangan perilaku maupun pola pikir siswa. Akan berdampak baik jika digunakan pada ranah mencari informasi penting guna memperdalam ilmu pengetahuannya terhadap mata pelajaran di sekolah. Namun akan berdampak buruk jika hanya digunakan untuk sekadar bermain game dan berselancar mencari situs web yang tidak seharusnya.

Sebagai guru, di era kali ini kita harus paham bahwa era pendidikan dengan pemanfaatan teknologi digital merupakan ciri dari pendidikan di masa revolusi 4.0 atau yang biasa disebut sebagai pendidikan 4.0, dimana dalam pembelajarannya disebut dengan sistem siber (cyber sistem) serta harus sanggup dalam menciptakan proses pembelajaran yang berlangsung secara berkala tanpa batas ruang dan waktu. Karena hal ini, guru di era digital diharuskan mampu membuat perubahan dalam penyampaian materi pembelajaran kepada siswa agar menjadi lebih mudah diterima. Seperti penerapan media pembelajaran berbasis teknologi yang dapat menarik perhatian dan motivasi belajar siswa.

Beberapa Upaya yang telah di lakukan oleh guru diantaranya dengan menggunakan beberapa aplikasi online seperti wordwall dan live worksheet namun dengan menggunakan media tersebut masih terkendala dengan kemampuan mendisain bahan ajar dan evaluasi sehingga aplikasi belum dapat diterapkan secara maksimal, Oleh karena itu inovasi dalam cara penyampaian materi yang berbeda sangat dibutuhkan siswa dimasa ini. Untuk menghilangkan kejenuhan siswa dalam belajar, penerapan media seperti kahoot sangatlah diperlukan. Karena dengan penggunaan media kahoot ini diharapkan siswa tidak hanya mengingat materi yang disampaikan tetapi juga dapat menarik antusias siswa dalam belajar dengan bermain meskipun secara daring. Sehingga dapat ditarik kesimpulannya bahwa manfaat media kahoot dalam proses pembelajaran adalah menjadi salah satu alternatif belajar siswa agar lebih efektif dan menarik untuk memahami materi yang disampaikan guru kepada siswa.

Kahoot adalah salah satu permainan berbasis platform pembelajaran yang berdiri berdasarkan proyek kerjasama Johan Brand, Morten Versik dan Jamie Booker dengan Universitas Sains dan Teknologi Norwegia. Bersama dengan Profesor Alf Inge Wang mereka bekerjasama dan bergabung dengan Norwegia Asmund Furuseth. Platform kahoot yang dikenal sebagai media pembelajaran interaktif dalam latihan soal dan pengayaan yang diberikan guru kepada siswa dengan memiliki empat fitur, yaitu game, diskusi, kuis, dan survey.

Pembelajaran dengan bantuan media kahoot menjadi alat yang dapat merangsang kemampuan visual dan verbal siswa. Platform kahoot yang dapat digunakan secara cuma-cuma tanpa berbayar, menjadi salah satu keuntungan yang diperoleh dari media berbasis teknologi ini. kahoot merupakan platform pembelajaran yang memiliki 2 halaman web yang dapat diakses oleh pengguna yaitu https://kahoot.com/ untuk guru dalam membuat kuis dan https://kahoot.it/ 
digunakan untuk siswa dalam memainkan kuis yang dilakukan baik secara individu maupun berkelompok.

Secara umum, hasil belajar merupakan perubahan dalam kemampuan pengetahuan, sikap, keterampilan dan perilaku siswa setelah kegiatan belajar. Menurut Sudjana (2011:22) hasil belajar merupakan kemampuan yang dimiliki siswa setelah menerima pengalaman belajarnya. Hasil belajar siswa diperoleh melalui proses belajar yang dimana akan dikatakan berhasil apabila dalam proses belajar tersebut menunjukkan suatu perubahan pada diri siswa. Tiga macam hasil belajar menurut Horward Kingsley dalam Sudjana (2011:22) yaitu: keterampilan dan kebiasaan, pengetahuan dan pengertian, sikap dan cita-cita. Sedangkan Gagne membagi lima kategori hasil belajar, yaitu: informasi verbal, keterampilan intelektual, strategi kognitif, sikap dan keterampilan motoris.

Hal tersebut diperkuat dengan pendapat Kusnandar (2013:62) yang menyatakan bahwa hasil belajar adalah suatu kompetensi atau kemampuan dalam hal tertentu baik itu kognitif, afektifnya maupun psikomotoriknya yang dicapai atau dikuasai siswa setelah mengikuti proses belajar. Berdasarkan pendapat Hamalik (dalam Nuryadi dan Nanang, 2001:89), evaluasi yang menjadi sistem instruksional melaksanakan beberapa fungsi di antaranya yaitu:

1) Fungsi Edukatif yang berguna untuk mendapatkan informasi tentang keseluruhan sistem/subsistem pendidikan.

2) Fungsi Insitusional berguna untuk mengumpulkan segala informasi yang akuran mengenai input dan output pembelajaran.

3) Fungsi Diagnostik yang digunakan dalam memperoleh informasi mengenai kesulitan yang sedang dihadapi siswa.

4) Fungsi Administratif dipergunakan untuk menyajikan data mengenai kemajuan belajar siswa dan biasa dicantumkan dalam memberikan tanda kelulusan.

5) Fungsi Kurikuler untuk menyediakan informasi dan data yang akurat dalam pengembangan kurikulum.

6) Fungsi Manajemen berguna sebagai bahan pimpinan dalam membuat keputusan manajemen.

Berdasarkan pendapat Wasliman (dalam Susanto, 2013:12) mengemukakan bahwa hasil belajar yang dicapai siswa berasal dari interaksi berbagai faktor yaitu:

1) Faktor Internal

Faktor yang berasal dari diri siswa. Dimana faktor ini contohnya seperti kecerdasan, motivasi belajar, kebiasaan belajar, minat, ketekunan, kondisi kesehatan dan kondisi fisik.

2) Faktor Eksternal

Faktor yang berasal dari luar diri peserta didik yang dapat mempengaruhi hasil belajar seperti kondisi keluarga, masyarakat sekitar dan sekolah.

Tujuan pada penelitian ini yang ingin dicapai dalam penelitian ini yaitu: (1) Mendeskripsikan penggunaan media kahoot pada pembelajaran tematik terhadap hasil belajar siswa kelas V Sekolah Dasar Islam Nurul Iman; (2) Mendeskripsikan hasil belajar siswa dengan penggunaan media kahoot pada pembelajaran tematik siswa kelas V Sekolah Dasar Islam Nurul Iman; (3) Mendeskripsikan respon siswa dalam penggunaan media kahoot pada pembelajaran tematik terhadap hasil belajar siswa kelas V Sekolah Dasar Islam Nurul Iman; (4) Mendeskripsikan hambatan pada penggunaan media kahoot dalam pembelajaran tematik terhadap hasil belajar siswa kelas V Sekolah Dasar Islam Nurul Iman. 


\section{METODE}

Metode penelitian yang digunakan dalam penelitian ini adalah metode penelitian dengan pendekatan kualitatif. Yang bertujuan untuk mendeskripsikan pengaruh penggunaan media kahoot dalam pembelajaran Tematik yang berfokus pada materi peristiwa proklamasi. Pada penelitian ini, memperoleh data dengan cara melakukan wawancara, observasi, tes dan juga pengisian kuisioner (angket). Walaupun data yang digunakan dapat dihitung, namun penyajian angka dianalisis secara kualitatif.

Data penelitian yang diperlukan dalam penelitian ini merupakan data verbal dan non verbal. Dimana data verbal yang diperlukan berupa hasil respon guru maupun siswa yang dilakukan dengan cara wawancara, pengerjaan tes, pengisian angket dan juga observasi yang dilakukan peneliti. Sedangkan data non verbal yang diperlukan berupa data hasil belajar siswa, daftar nama siswa, data profil sekolah, dan juga buku tema siswa Kurikulum 2013 Revisi 2017 Tema 7 Peristiwa dalam Kehidupan Subtema 2 dengan materi Peristiwa Kebangsaan Seputar Proklamasi Kemerdekaan beserta materi ajar tambahan.

Teknik pengumpulan data yang dilakukan peneliti untuk mendapatkan data dan informasi berupa Teknik Wawancara, Teknik wawancara yang dilakukan dengan terstruktur. Dalam wawancara ini dilakukan kepada guru dan siswa kelas VB Sekolah Dasar Islam Nurul Iman. Karena masih dalam masa pandemi covid-19 dan masih harus melaksanakan protokol kesehatan, sehingga wawancara dilakukan secara virtual melalui media WhatsApp. Teknik Hasil Belajar Siswa Pada Teknik evaluasi ini, diberikan kepada siswa dalam bentuk digital yang ditampilkan melalui media kahoot. Pada Teknik ini juga digunakan dalam mengukur hasil belajar siswa. Teknik Angket Teknik angket yang diberikan kepada siswa sebagai responden. Angket diberikan secara daring melalui pranala google form. Angket ini diperlukan guna mengetahui respon dari siswa mengenai pembelajaran melalui media kahoot. Sehingga peneliti dapat mengetahui tingkat keefektivan media kahoot. Untuk mengukur tingkat pengaruh penggunaan media dalam penelitian ini, diolah dengan menganalisis jawaban berdasarkan Skala Likert. Berdasarkan buku Evaluasi pembelajaran Asrul Ananda, Rosnita, (2014:106), Skala Likert adalah skala pengukuran yang digunakan untuk mengukur sikap terhadap sesuatu yang dimana skala ini terdapat dua unsur yaitu pernyataan yang dapat berupa pernyataan dalam bentuk positif maupun negatif dan alternatif jawaban yang terdiri dari tidak setuju, kurang setuju, netral, setuju, dan sangat setuju. Sehingga skala ini dapat dijadikan acuan dalam melakukan analisis hasil respon siswa maupun guru dalam pengisian jawaban melalui angket yang diedarkan. Teknik analisis data yang dilakukan ini terdapat beberapa tahap diantaranya yaitu sebagai berikut:

1) Pengumpulan data

Tahap awal yang dilakukan dengan melakukan pengumpulan data yang didapatkan dari sumber data yang telah di tentukan sebelumnya.

2) Reduksi data

Pada tahap ini, proses analisis dilakukan untuk memusatkan dan menyederhanakan hal-hal yang dianggap penting dan membuang hal-hal yang dianggap tidak perlu. Dengan memilih data yang dianggap penting, kemudian membuat kategori data lalu mengelompokkan data pada kategori yang telah dibuat.

3) Penyajian data

Penyajian data diarahkan dengan menyusun data yang di jelaskan secara deskriptif dan saling keterkaitan sehingga informasi yang dirangkum mempunyai makna tertentu.

4) Verifikasi data.I 
Pada tahap ini, perlu melakukan bukti-bukti yang lebih mendukung lagi sehingga kesimpulan kedua dari tahap verifikasi data jauh lebih valid.

\section{HASIL DAN PEMBAHASAN}

Dari hasil penelitian yang telah dilakukan, terlihat bahwa selama dua kali pertemuan yang diamati peneliti dalam pelaksanaan pembelajaran, guru melaksanakan pembelajaran dengan sangat baik dan runtut. Cara guru membuka kelas Teams, mengajak siswa berdoa bersama dan melakukan apresepsi sebelum pembelajaran dilakukan guru dengan sangat baik. Dimana respon siswa diawal pembelajaran juga terlihat sangat baik dan santun. Mengucapkan salam saat pertama memasuki kelas juga menjadi kebiasaan yang baik bagi siswa.

Dengan dilakukannya simulasi penggunaan media Kahoot pada pertemuan pertama, guru melakukan persiapan dan diikuti oleh siswa yang juga mengikuti langkah-langkah sesuai arahan guru. Setelah selesai persiapan masuk, kemudian siswa dapat mememulai pengerjaan kuisnya. Dari pertemuan pertama dengan pemberian materi serta pelaksanaan simulasi media, peneliti dapat melakukan penilaian selama pembelajaran yang tengah berlangsung. Sehingga peneliti dapat memperoleh data yang akan dianalisis lebih lanjut.

Pada Kegiatan wawancara dilakukan kepada guru kelas VB Sekolah Dasar Islam Nurul Iman, yang dilaksanakan secara daring melalui Video Call Whatsapp. Berdsarkan wawancara yang dilakukan, Pada pertanyaan mengenai tanggapan guru selama pembelajaran menggunakan media Kahoot mendapat respon yang baik. Pada pertanyaan tersebut guru menyampaikan bahwa selama pembelajaran menggunakan media Kahoot, antusias siswa dalam mengikuti kuis dan mengerjakan soal terlihat berbeda. Ketertarikan mereka dan rasa ingin tahu mereka dengan soal yang diberikan begitu terlihat ketika mereka meminta untuk segera beralih ke pertanyaan berikutnya. Kesimpulan yang dapat diambil peneliti yaitu bahwa dengan adanya media kahoot ini guru merasa senang dengan perubahan antusias siswa dalam menyelesaikan kuis dan memahami materi yang disampaikan oleh guru. Ketika siswa diberi pertanyaan yang berkaitan dengan kefokusan dalam mengerjakan soal dan pemahaman siswa mengenai materi yang telah diberikan. Siswa mengaku lebih fokus dalam mengerjakan soal karena setiap soal diberi batas waktu dalam pengerjaan, sehingga mereka merasa lebih fokus dalam mengerjakan. Materi yang diberikan oleh guru jadi lebih mudah dipahami dan lebih mudah diingat oleh siswa.

Evaluasi dengan menggunakan media kahoot memang meberikan suasana yang berbeda dari biasanya. Maka, berdasarkan hasil wawancara kepada guru mengenai pembelajaran dimasa pandemi dan penggunaan media kahoot, menunjukkan bahwa adanya kevektifan menggunakan media tersebut. Maka, berdasarkan hasil wawancara kepada guru mengenai pembelajaran dimasa pandemi dan penggunaan media kahoot, menunjukkan bahwa selama pandemi proses pembelajaran yang dilaksanakan secara daring melalui kelas Teams. Penyampaian materi oleh guru kepada siswa biasanya hanya berupa pdf yang diunggah guru melalui saluran Teams. Kemudian dengan adanya media kahoot, guru merasa terbantu dalam mengkondisikan siswa. Artinya, selama proses pembelajaran berlangsung yang biasanya siswa mengalami kebosanan dalam menerima materi, kurang kondusifnya suasana meski dalam pembelajaran secara daring. Dengan adanya media kahoot, guru dapat mengajak siswa untuk mengerjakan kuis sambil bermain. Siswa yang awalnya bosan bisa menjadi penasaran dengan pebelajaran yang diberikan. 
Media kahoot juga dapat membantu guru dalam memotivasi siswa selama proses belajar mengajar. Hal ini terbukti selama pemberian kuis dalam memperdalam pemahaman siswa, guru dapat melihat kecepatan siswa dalam menjawab setiap butir soal. Dalam kesempatan inilah dipergunakan guru untuk membangkitkan motivasi belajar siswa terutama bagi siswa yang kurang menonjol dalam belajarnya. Selain media ini dapat memotivasi siswa. Media ini juga dapat membuat antusias siswa dalam belajar dan menjadi lebih fokus dalam menerima materi yang disampaikan oleh guru.

Kegiatan untuk mengetahui hasil belajar siswa, peneliti menggunakan instrumen evaluasi pembelajaran yang diberikan kepada siswa secara daring dalam bentuk kuis melalui media kahoot. Pada kuis kali ini, soal yang diberikan sama seperti soal pada saat pertama simulasi, namun soal diberikan secara acak serta waktu pengerjaan perbutir soal lebih dipercepat dari waktu pada saat simulasi. Pengerjaan kuis ini, siswa sudah paham dengan cara kerja media, namun 2 dari 6 kelompok mengalami kendala pada sinyal. Sehingga pengerjaan yang dilakukan kurang maksimal.

Berikut hasil dan analisa peneliti:Dilihat dari pengerjaan evaluasi siswa, terlihat pada butir soal nomor 8 dan 9 sebesar $0 \%$. Pada nomor soal 8 dan 9 tidak termasuk kedalam soal sulit karena pada soal tersebut, keluar dalam kondisi jaringan internet siswa mengalami koneksi yang kurang stabil sehingga terhitung sebagai soal yang dilewati dan tidak dikerjakan siswa.Pada data lainya terlihat bahwa 1 dari 10 soal tergolong sebagai soal yang sulit bagi siswa. Dimana hal tersebut ditunjukan dengan besar jawaban siswa sebanyak $25 \%$ dari yang jumlah siswa. Hasil pengerjaan soal berupa kuis yang dijalankan menggunakan media kahoot, terlihat bahwa siswa jauh lebih mudah dalam memahami materi yang diberikan daripada pemberian soal secara daring seperti biasanya. Pada Pembahasan dalam hal ini ada beberapa alasan salah satunya yaitu karena selama ini pemberian soal daring seperti biasanya, guru tidak dapat melihat adanya perubahan pada diri siswa terutama pada siswa yang memang masih kurang dalam pembelajarannya. Meskipun dalam pengerjaan terdapat soal yang masih sulit bagi siswa. Namun ketika guru mengulas kembali saat refleksi diakhir pembelajaran, siswa masih sangat antusias dalam menjawab pertanyaan yang dilontarkan oleh guru.

Maka, berdasarkan hasil pengerjaan soal berupa kuis yang dijalankan menggunakan media kahoot, terlihat bahwa siswa jauh lebih mudah dalam memahami materi yang diberikan daripada pemberian soal secara daring seperti biasanya. Karena selama ini pemberian soal daring seperti biasanya, guru tidak dapat melihat adanya perubahan pada diri siswa terutama pada siswa yang memang masih kurang dalam pembelajarannya. Meskipun dalam pengerjaan terdapat soal yang masih sulit bagi siswa. Namun ketika guru mengulas kembali saat refleksi diakhir pembelajaran, siswa masih sangat antusias dalam menjawab pertanyaan yang dilontarkan oleh guru.

Daya ingat, antusias dan cara siswa fokus dalam pembelajaran juga menunjukkan perubahan yang baik. Dimana biasanya hanya beberapa siswa dalam tanya jawab diakhir kegiatan yang menjawab, kini hampir semua siswa ikut serta dalam menjawab pertanyaan. Kemudian antusias dan kefokusan siswa dalam mengerjakan soal terlihat ketika siswa meminta untuk segera diganti ke soal berikutnya, hal tersebut terlihat jelas ketika soal telah dibuka, suasana hening dalam menjawab soal-soal kuis. 
Angket respon siswa diisi isi oleh responden secara daring melalui pranala google form. Yang disajikan dalam bentuk diagram dan di rekap dengan hasil sebagai berikut:

Tabel 4. 1 rekap hasil respon angket siswa

\begin{tabular}{|c|c|c|c|c|}
\hline No & Aspek yang dinilai & 1 & 2 & 3 \\
\hline 1 & Aplikasi kahoot mudah dioperasikan & 3 & 13 & 2 \\
\hline 2 & Tampilan kahoot menarik bagi saya & 1 & 14 & 3 \\
\hline 3 & $\begin{array}{l}\text { Pembelajaran menggunakan kahoot membantu saya } \\
\text { memahami materi peristiwa proklamasi }\end{array}$ & 1 & 11 & 6 \\
\hline 4 & $\begin{array}{l}\text { Pembelajaran menggunakan kahoot sanagat } \\
\text { menyenangkan }\end{array}$ & 0 & 12 & 6 \\
\hline 5 & $\begin{array}{l}\text { Pembelajaran menggunakan kahoot membuat saya } \\
\text { termotivasi untuk terus belajar }\end{array}$ & 0 & 10 & 8 \\
\hline 6 & $\begin{array}{l}\text { Kuis di kahoot membuat rasa ingin tahu saya } \\
\text { bertambah }\end{array}$ & 3 & 10 & 5 \\
\hline 7 & Kuis di kahoot membuat saya menjadi lebih fo & 1 & 12 & 5 \\
\hline 8 & Kuis di kahoot membuat saya merasa tertantang & 1 & 15 & 2 \\
\hline & Saya asal dalam mengerjakan kuis di kahoot & 12 & 5 & 1 \\
\hline \multicolumn{2}{|c|}{ Jumlah } & 22 & 102 & 38 \\
\hline
\end{tabular}

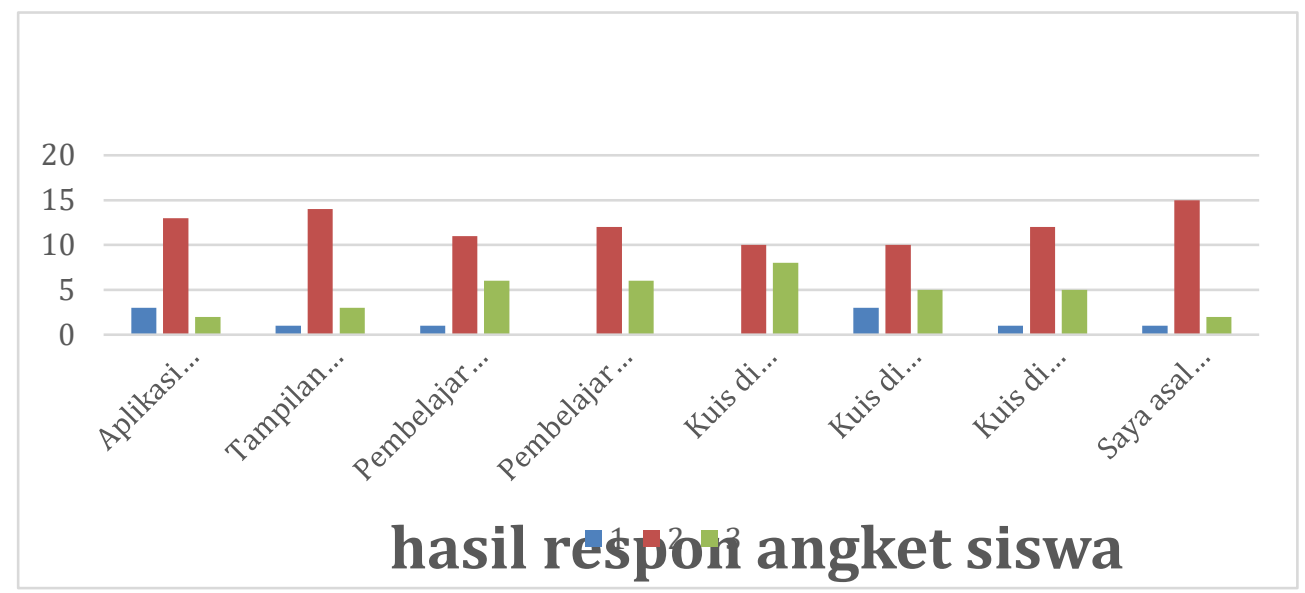

Gambar 4.3 Hasil Respon Angket Siswa

Dari segi pendapat siswa yang dituangkan dalam menjawab angket, seperti pada tabel 4.3, respon siswa dengan lebih banyak memilih setuju. Dan dari hasil analisis yang dilakukan peneliti terhadap hasil pengisian angket, terlihat bahwa respon siswa dalam menggunakan media kahoot sangat antusias dan dan membuat siswa jauh lebih termotivasi. Dari segi pendapat siswa yang dituangkan dalam menjawab kuisioner, seperti bagan gambar 4.2.3.1, respon siswa dengan lebih banyak memilih setuju. Data tersebut membuktikan bahwa siswa merasa setuju dengan media Kahoot menjadi media yang mudah dioperasikan dan menarik bagi mereka. Meskipun terdapat jawaban siswa yang menyatakan tidak setuju apabila media Kahoot menjadi media yang mudah dioperasikan, hal ini tidak membuat media ini tergolong sulit dioperasikan. Sulitnya dioperasikan bisa karena faktor koneksi internet yang tidak stabil pada lokasi siswa, sehingga dalam menggunakannya akan merasa kesulitan masuk. 
Analisa yang dilakukan peneliti berdasarkan Skala Likert, dengan sistem penilaian item favorable, dapat disimpulkan dimana dari data tersebut dapat diketahui bahwa dari segi pendapat guru yang dituangkan dalam menjawab kuisioner menyatakan bahwa guru sangat setuju dengan pembelajaran menggunaan media Kahoot ini. Karena selain media mudah dioperasikan, media ini juga dapat membantu guru dalam mengkondisikan siswa terutama dalam hal menarik fokus dan konsentrasi siswa dalam memahami materi yang diberikan. Adapaun kelebihan media Kahoot terkiat dengan beberapa penelitian yang sudah dilaksanakan yaitu media Kahoot untuk mengkondisikan kelas pada saat pembelajaran mata pelajaran Pendidikan Agama Islam dan dapat dapat meningkatkan aktifitas pembelajaran agar dapat meningkatkan prestasi belajar siswa (Khabidin, 2019). Selain itu, penggunaan Media Kahoot Pada Kegiatan Penutup Pembelajaran yang bisa di pakai untuk mefokuskan pembahasan mengenai terlaksananya kegiatan penutup dalam kegiatan proses pembelajaran (Desyana, 2019).

\section{SIMPULAN}

Berdasarkan hasil penelitian penggunaan media kahoot pada pembelajaran tematik yang berfokus pada materi peristiwa proklamasi dan dilaksanakan selama 2 hari pada siswa kelas VB Sekolah Dasar Islam Nurul Iman Benowo Surabaya, dapat diperoleh hasil yang disimpulkan sebagai berikut:

1. Berdasarkan hasil wawancara yang telah dilakukan peneliti kepada guru kelas, menunjukkan bahwa penggunaan media kahoot pada pembelajaran tematik terhadap hasil belajar siswa kelas V Sekolah Dasar Islam Nurul Iman sangat baik.

2. Berdasarkan Hasil belajar siswa dengan penggunaan media kahoot pada pembelajaran tematik siswa kelas $\mathrm{V}$ Sekolah Dasar Islam Nurul Iman mengalami perubahan yang baik. Terlihat dari lebih mudahnya siswa dalam memahami materi yang diberikan.

3. Berdasarkan pengisian angket, respon siswa dalam penggunaan media kahoot pada pembelajaran tematik terhadap hasil belajar siswa kelas V Sekolah Dasar Islam Nurul Iman sangat baik. Siswa menjadi lebih tertantang dan fokus dalam mengerjakan soal serta mengingat materi.

\section{DAFTAR PUSTAKA}

Arsyad, Azhar. (2013). Media Pembelajaran. Jakarta: PT RajaGrafindo Persada.

Asrul, Rusydi Ananda., dan Rosnita. (2014). Evaluasi Pembelajaran. Bandung: Citapustaka Media.

Bahar, Herwina, dkk. (2020). Efektifitas Kahoot Bagi Guru Dalam Pembelajaran Di Sekolah Dasar. Jurnal Pengambidan pada Masyarakat Vol.3 (2): hal 155-162

Bunyamin, Aceng Cucu,. Juita, Dewi Rika, dan Syalsiah, Noer. Penggunaan Kahoot Sebagai Media Pembelajaran Berbasis Permainan Sebagai Bentuk Variasi Pembelajaran. Jurnal Kehumasan Vol.3 (1): hal 44-48.

Centauri, Beta. (2019). Efektivitas Kahoot! Sebagai Media Pembelajaran Kuis Interaktif Di SDN-7 Bukit Tunggal. Diakses 06 Mei 2021, dari Teknologi Pendidikan, FKIP, Universitas Palangka Raya.

Danuri dan Siti Maisaroh. (2019). Metode Penelitian Pendidikan. Yogyakarta: Samudra Biru.

Nuryadi dan Nanang Khuzaini. (2016) "Evaluasi Hasil dan Proses Pembeleajaran Matematika”. Yogyakarta: Leutikaprio.

Sidiq, Umar dan Moh.Miftachul Choiri. (2019). Metode Penelitian Kualitatif Di Bidang Pendidikan. Ponorogo: Nata Karya. 
Sugiyono. (2017). Metode Penelitian Kuantitatif, Kualitatif, Dan R\&D. Bandung: Alfabeta. Desyana, Lucia Vita. (2019). Efektivitas Penggunaan Media Kahoot Pada Kegiatan Penutup Pembelajaran Matematika Di Kelas III SD .

Khabidin. (2019). Efektifitas Penerapan Aplikasi Kahoot Dalam Mengkondisikan Kelas Pada Kelas 5 SD. 